\title{
Customer Satisfaction of Different Brands of Hero Honda Motors at Rao \& Khan Motors, Krishnagiri
}

\author{
R. Ramamoorthy, S. Soundarya, Pallavi Kumari
}

\begin{abstract}
In the time of globalization electronic showcasing is an incredible upset. In the course of the most recent decade greatest business associations are running with innovative change. Internet shopping or advertising is the utilization of innovation (i.e., PC) for better showcasing execution. Also, retailers are formulating techniques to fulfill the need of brands; they are occupied in contemplating customer conduct in the field of various brands of engines, to see the purchaser mentalities. Consequently we have additionally chosen to examine customer's frames of mind and explicitly concentrating the components affecting purchasers to shop.
\end{abstract}

\section{Keywords: Shopping, Consumer Behavior, Attitude}

\section{INTRODUCTION}

\section{A. Definition Of Some Concept}

In modern marketing concept, all marketing activities have to revolve around the customers or consumers. Effective marketing requires a clear picture of the consumers characteristics that can be described as the "Customer Profile". Marketing effort should be towards the specific group of people or segment[1],[3],[5]

Market segmentation is the process of diving a market into distinct sub-set of consumers with common needs or characteristics and selecting one or more segments to target with a district marketing mix".

According to Cundiff and Still "market segmentation consists of taking the total heterogeneous market for a product and dividing it into several sub-markets or segments each of which tends to be homogenous in tall significant aspects".

These segmentation studies to discover the needs and works of specific groups of consumers. So that specialized good and services can be developed and promoted to satisfy each groups needs.

According to Philip Kotler, consumer market can be segmented on the basis of four variables such as Demographic, Geographic, psychological and Behavioral.

\section{B. Consumers}

Revised Manuscript Received on July 22, 2019.

Mr. R. Ramamoorthy, Department of MBA, Bharath Institute of Higher Education and Research, Chennai, India.

Email: ramamoorthy0071@gmail.com

S. Soundarya, Department of MBA, Bharath Institute of Higher Education and Research, Chennai, India.

Email: soundarya43@gmail.com

Pallavi Kumari, Department of MBA, Bharath Institute of Higher Education and Research, Chennai, India.

Email: pallavikumar43@gmail.com
The consumers are the persons who buy things for their own satisfaction. Consumers buy small quantities of goods for their needs buying by consumers depends upon their income. "The term consumer refers to the potential purchaser's of product and services offered for sale". The person who buys the product is called as the buyer.

\section{Basis Of Market Segmentation}

\begin{tabular}{llll|}
\hline & \multicolumn{1}{|c|}{} \\
Demographic & Geographic & Psychological & \multicolumn{1}{|c|}{ Behavioral } \\
1. Age & 1. Regions & 1. Learning & 1. Occasion \\
2. Sex & 2. Villages & 2. Motivation & 2. Benefits \\
3. Family Size & 3. Cities & 3. Life style & 3. User status \\
4. Income & 4. Density & 4. Personality & 4. Usage Rate \\
5. Occupation & 5. Climate & 5. Perception & 5.Brand Loyalty \\
6. Education & & 6. Attitudes & \\
7. Religion & & & \\
8. Nationality & & &
\end{tabular}

Consumers behavior is the study of how individuals make decision to spend their available resources (Time, Money, Effort) on consumption related items[2],[4],[6]".

Consumers satisfaction refers to a person's feelings and pleasure or disappointment resulting from comparing a products perceived performance (or outcome) in relation to his or her expectation.

According to Pyle "Buying comprises all those activities involved in finding a suitable source of supply, selecting the desired quantity, quality, grade, style and size and coming to an agreement with reference to the prices delivery data and other conditions[7],[9],[11]".

\section{Perception}

Perception is the process by which individuals select, organize and interpret stimuli into a meaning full and coherent picture of the world.

\section{E. Product}

According to Philip Kotlar, a product is anything that can be offered to market for attention acquisition, use or consumption that might satisfy a want or need. If includes. Physical objects services, persons, organisation and ideas" A product is always a bundle of attributes. These attributes includes physical factors e.g. color, design, feature, 
performance and Non-physical factors e.g. Utility, values quantity.

A product is very often described as "Quick mover" when all these attributes are present[8],[10],[12].

\section{Features Of Product}

1) Tangibility :

If should be perceptible by the touch. An item to be called a product, should have an tangibility character - touch, seen or feeling for instance, car, shirt, book etc.

\section{2) Intangible Attributes :}

The product may be intangible, in the form of services, for instance, banking insurance services, repairing etc. it is an associated feature. For instance, motorcycle is a tangible product, and when the seller offers free servicing, and then the product is not only a tangible item but also an intangible one[13], [15],[17] .

\section{3) Associated Attributes:}

Such attributes may be brand, package, warranty etc.

\section{4) Exchange Value :}

Whether the product is tangible or intangible it should have exchange value and must be capable of being exchanged between seller and buyer for mutual agreed price.

A company cannot always be success in selling poor products in the market over the long run. The survival and growth of the product depends upon many activities that make the product more acceptable to the intended customers. The product concept of three-levels.

\section{1) The Core Product}

2) Related Product Features

3) Related Product Services

\section{1) Core Product}

The product or service has certain immediately identifiable characteristics and functions that distinguish it from other products or services. The most fundamental level is the core product, which answers the question. "what is the buyer really buying"?.

\section{2) Related Product Features}

These includes the brand name the type of packaging safety components etc.

\section{3) Related Product Service}

These includes such as delivery, installation, maintenance, repairs, free service, guarantee etc of the product.

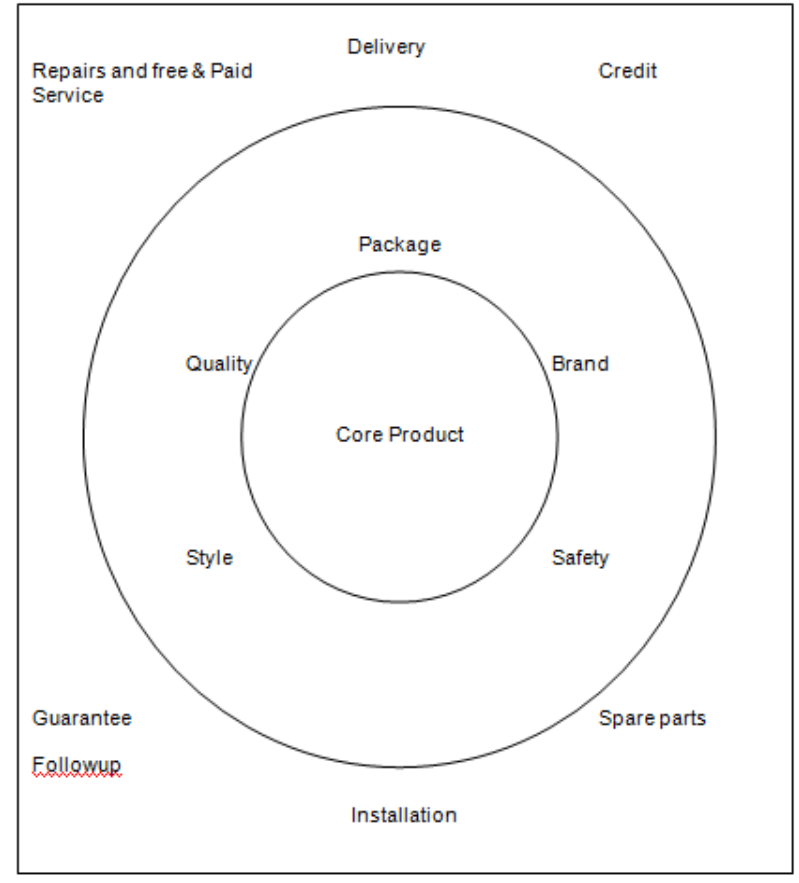

\section{PRODUCT LINE}

According to Stanton "A Broad group of products, instended for essentially similar uses and possessing reasonably similar physical characteristics, constitute a product line"

\section{BRAND}

Americal Marketing Association defines a brand as "The use of a name, term, symbol or design or some combination of these, to identify the product of a certain seller from those of competitions. "A brand identifies the product for a buyer. A Seller can earn the goodwill and have the patronage repeated[14],[16], [18].

\section{ADVANTAGES OF BRAND NAMES}

1. It is device by which a good image and good will are established.

2. It distinguishes products from rival firms and thus ensures constant returns.

3. It widens the markets, through demand creation.

4. It reduces the advertising cost and brings repeated sales if the brand name sets popular.

5. Individuality of a product is establishment.

\section{TO CONSUMERS}

1) Brand distinguishes and differentiates the products of different manufacturers.

2) Consumers are assured to get quality and standard products.

3) Many people get satisfaction as certain brands, which are in great popularity.

4) It offers an easy way for purchase by easily identifying a product. 


\section{TO DISTRIBUTORS}

1) Branded goods require less time to get sold

2) Branding aid's in advertising and display programmes

3) Branding reduces the price comparison and helps stabilize price

4) Special selling efforts need not be undertaken.

\section{BUYING MOTIVES}

Purchasing intentions allude to thought, ask, solid sentiments, feeling, drives and so on., they make a purchaser to respond as a choice. Rationale incite a purchaser to buy a specific item. The thought processes might be commonly constrained by conservative, social, mental impact, and so on.

At the point when a customer purchases an item, his points or want to have security. Individuals buy items encouraged by mental and financial powers, which make a longing and this craving is fulfilled by the articles showed available to be purchased[19],[21],[23].

The investigation on the purchaser conduct is fundamental to comprehend what advertising is the achievement or disappointment in showcasing relies on the individual, responses, communicated through purchasing behavior.

The capacity of promoting are worried about interest. Its acknowledgment, expectation, incitement, lastly fulfillment. In any case, before obtaining a specific item, one much know about acknowledgment of something about that specific item. Under such conditions, the merchandise are to be purchased with the assistance of depiction outfitted by the provider. The depiction is given as a represented voucher or index or envelope, one may get brand consciousness of one item from his companion and relatives, neighbors and vendors moreover.

\section{RESEARCH METHODOLOGY}

A research design is purely and simply the basic frame work for a study that guides the collection of data and analysis of the data. A mixture of exploratory and descriptive research design as adopted for this study to achieve the objectives of the study[20],[22],[24].

Exploratory research studies are also termed as "FORMULA RESEARCH" studies. This type of research designis more flexible to carry out the research. The design provides the opportunity for considering different aspect of the problem. Descriptive study is typically concerned with determining frequency with which something occurs. Descriptive research process seeks to determine the answer to why? What?How?Who?
Table - 1: Showing No Of Respondent For Each Brands

\begin{tabular}{|l|l|}
\hline \multicolumn{1}{|c|}{ BRAND NAME } & \multicolumn{1}{c|}{ NO.OF. RESPONDENTS } \\
\hline Hero Honda Splendor & 50 \\
Hero Honda Dawn & 50 \\
Hero Honda Passion & 50 \\
Hero Honda CD 100 & 50 \\
\hline TOTAL & \\
\hline
\end{tabular}

\section{A. Data Analysis And Interpretation}

The researcher prepares a questionnaire and circulated among 200 respondents who visited M/s. Rao \& Khan Motors, Krishnagiri during the training period of find out their satisfaction about different brands (Particularly Splendor, Passion, Dawn and CD-100) the data so collected are analysed and interpreted in the following pages.

\section{Data Analysis :}

The collected data from the 200 respondents are analyzed with the help of the following statistical tools.
1)
2)
Percentage
Ranking

\section{$\underline{\text { AGE }}$}

Young blood like's to have speedy vehicles. While aged people give importance for safety, petrol consumption, cost etc., so age is one of the important factors determining consumer buying behavior with regard to two - wheeler. A study is carried an how far age of respondents affects the purchase of different brands.

Table - 2: Showing Affect Of Age On Purchase Of Different Brands

\begin{tabular}{|c|c|c|c|c|c|}
\hline Brand & \multicolumn{4}{|c|}{ Hero Honda } & \multirow{2}{*}{ Total } \\
\cline { 1 - 5 } Age & Splendor & Dawn & Passion & CD 100 & \\
\hline Below - 20 yrs & 7 & 4 & 6 & 4 & 21 \\
\hline $21-30$ yrs & 27 & 23 & 28 & 24 & 102 \\
\hline $31-45$ yrs & 12 & 15 & 12 & 10 & 49 \\
\hline Above-45 yrs & 4 & 8 & 4 & 12 & 28 \\
\hline Total & 50 & 50 & 50 & 50 & 200 \\
\hline
\end{tabular}

The above table clearly reveals that out of 200 respondents 102 belongs to 21-30 years age group majority of them prefer Hero Honda Passion, followed by Splendor, CD100 and 


\section{Customer Satisfaction of Different Brands of Hero Honda Motors at Rao \& Khan Motors, Krishnagiri}

Dawn, 49 respondents belong to 31-45 years age group majority of them prefer Hero Honda Dawn followed by splendor, passion and CD100. [25],[27],[29] 28 respondents belong to above 45 years age group - Majority of them prefer Hero Honda CD-100,

followed by Dawn, Splendor and Passion - 21 respondents belong to below 20 years age group. Majority of them Splendor, followed by passion, Dawn and CD 100.

Table - 3 Consumers Ranking Age Wise Consumers Preferece On The Most Attractive Brand Of Motor Cycles.

\begin{tabular}{|c|c|c|c|c|c|c|c|c|}
\hline $\begin{array}{c}\text { Age } \\
\text { Brand }\end{array}$ & \multicolumn{2}{|c|}{ Below-20 } & \multicolumn{2}{c|}{$21-30$} & \multicolumn{2}{c|}{$31-45$} & \multicolumn{2}{c|}{ Above 45 } \\
\hline & Score & Rank & Score & Rank & Score & Rank & Score & Rank \\
\hline Splendor & 7 & I & 27 & II & 12 & II & 4 & III \\
\hline Dawn & 4 & III & 23 & IV & 15 & I & 8 & II \\
\hline Passion & 6 & II & 28 & I & 12 & II & 4 & IV \\
\hline CD 100 & 4 & IV & 24 & III & 10 & IV & 12 & \\
\hline Total & 21 & & 102 & & 49 & & 28 & \\
\hline
\end{tabular}

The above table clearly depicts the age wise consumer preference on the attractive Motor - Cycle brands. The researcher classifies respondents into 4 categories. In the below 20 Age group splendor Scores I Rank followed by Passion - II, Rank Dawn and CD 100 Ranked III and IV.

In 21-30 AGE group Passion Scores I Rank followed by Splendor II rank CD 100, III Rank and dawn IV Rank.

In 31-45 AGE group Dawn scores I Rank followed by Splendor and Passion II Rank and III Rank and CD 100 scores IV Rank.

In above 45 age group CD 100 Scores I Rank Followed by Dawn II Rank splendor and Passion scored III Rank \& IV Rank respectively.

Table - 4: Showing Preference Of Different Brands By Married \& Un-Married Respondents / Consumers.

\begin{tabular}{|c|c|c|c|c|c|}
\hline Brand & \multicolumn{4}{|c|}{ Hero Honda } & \multirow{2}{*}{ TOTAL } \\
\cline { 1 - 4 } $\begin{array}{c}\text { Marital } \\
\text { Status }\end{array}$ & Splendor & Dawn & Passion & CD 100 & \\
\hline Married & 24 & 30 & 24 & 26 & 104 \\
\hline Un-Married & 26 & 20 & 26 & 24 & 96 \\
\hline Total & 50 & 50 & 50 & 50 & $\mathbf{2 0 0}$ \\
\hline
\end{tabular}

The above table clearly depicts that out 200 respondents, 104 respondents are married. Majority of the prefer Dawn followed by CD 100, Splendor and passion 96, respondents are un married. Majority of them prefer splendor and passion followed by CD 100 and Dawn.

\section{Educational Qualifications}

When respondent have more Educational Qualification they will have more analyzing capacity and there by their buying behavior will differ based on their expectation and satisfaction level. A study is carried on how far education of the respondent affects purchase of different brands.

Table - 5: Showing Effect On Education On Purchase Of Different Brand

\begin{tabular}{|c|c|c|c|c|c|}
\hline \multirow{2}{*}{$\begin{array}{c}\text { Brand } \\
\text { Education }\end{array}$} & \multicolumn{4}{|c|}{ Hero Honda } & \multirow{2}{*}{ TOTAL } \\
\hline & Splendor & Dawn & Passion & CD-100 & \\
\hline S.S.L.C. & 14 & 9 & 17 & 16 & 56 \\
\hline H.S.C. & 9 & 10 & 21 & 19 & 59 \\
\hline Degree & 27 & 31 & 12 & 15 & 85 \\
\hline Total & 50 & 50 & 50 & 50 & 200 \\
\hline
\end{tabular}

The above table depicts that out of 200 respondents, 85 respondent have completed degree course. Majority of them prefer Hero Honda Dawn, followed by Splendor, CD 100 \& Passion 59 respondents have completed HSC. Majority of them prefer Hero Honda Passion, followed by CD 100, Dawn and Splendor, 56 respondents have completed S.S.L.C. only Majority of them prefer Hero Honda Passion, followed by CD 100, Splendor and Dawn.

Table - 8: Showing Education Wise Raking Of Consumer Preference Different Brands

\begin{tabular}{|c|c|c|c|c|c|c|}
\hline \multirow{2}{*}{$\begin{array}{c}\text { Educational } \\
\text { Brand }\end{array}$} & \multicolumn{2}{|c|}{ S.S.L.C } & \multicolumn{2}{c|}{ H.S.C. } & \multicolumn{2}{c|}{ Degree } \\
\cline { 2 - 7 } & Score & Rank & Score & Rank & Score & Rank \\
\hline Splendor & 14 & III & 9 & IV & 27 & III \\
\hline Dawn & 9 & IV & 10 & III & 31 & I \\
\hline Passion & 17 & I & 21 & I & 12 & IV \\
\hline CD 100 & 16 & II & 19 & II & 15 & III \\
\hline Total & $\mathbf{5 6}$ & & $\mathbf{5 9}$ & & $\mathbf{8 5}$ & \\
\hline
\end{tabular}

The above table clearly depicts the education wise consumer preference on the most attractive motor cycle brands.

The researcher classifies respondents into 3 categories in S.S.L.C group passion scores I Rank, followed by CD 100 II, Splendor II, Rank Dawn II and Splendor Scores IV Rank.

In Degree group Dawn Scores I Rank, followed by Splendor II, Rank CD 100 III Rank and Passion Scores IV Rank

\section{RESULTS}

1) It is found that out of 200 respondents about 102 respondents belong to age group of 21- 30 yrs and 49 respondents belongs to age group of $31-45$ years, 28 respondents belongs to group age of above 45 years and 21 respondents belongs to age group of 21-30 years.

2) 104 respondents were married but only 96 were Un married.

3) It is found that 85 repondents have completed degree and 56 and 
59 respondents were S.S.L.C and H.S.C respectively.

4) 69 respondents do business, 53 respondents do profession, 40 respondents engaged in Agiculture and 38 respondents are students.

5) It is found that 82 respondents belong to Rs. $10,000-$ 15,000 Income group and 73 respondents belong to below Rs. 10000 income group, 45 respondents belong to above Rs. 15,000 income group.

6) Out of 200 respondents about 80 respondents have been bought their vehicle through their self interest, 47 respondents have purchased their vehicle on seeing advertisements.

7) 86 Respondents have been given their opinion that their vehicles price is normal[26],[28],[30].

8) Majority of the respondents i.e. $62 \%$ of respondent have given their reason for selecting their vehicle is fuel consumption.

9) Most of Dawn and Passion respondent feel good with the maintenance cost of the vehicle and only few respondents feel fair with the maintenance cost.

10) Most of the splendor and Dawn respondents feel good with the load capacity of the vehicle.

11) It has found that the splendor and Dawn respondents feel much easy with the handling- up of the vehicle when compare to CD 100.

12) Most of the respondent of Dawn and Passion feel that the lighting facility is fair.

13) Most of respo0ndents of Splendor and CD 100 feel excellent with the colour and design. When compare to other vehicles.

14) It is found that out of 200 respondents about 94 respondents feel good with the overall performance of the vehicle.

15) It shows that majority of the people that is out of 200 respondents 94 respondents feel that the availability of spares is good.

\section{DISCUSSIONS}

1) Most of the respondents feel that they have problem in lighting facilities. So, the researcher suggests the organization to implement effective lighting technique.

2) Most of the respondents feel that the cost of spares of is not fair, so the Manufactures(of particular splendor, Dawn) should concentrate in this area.

3) Most of respondents fell that the only draw back in passion is less road grip and low break. So the manufacturer should concentrate in this area.

4) Most of the respondents feel that the only drawback in $C D$ 100 is low break engine noise and lighting. So the manufacture should concentrate is this area.

5) Most of the respondents feel fair about the free service facilities, the manufacturer can given additional free service facilities to the consumer of all brands.

\section{CONCLUSION}

The study reveals that most of the respondents prefer Splendor in Hero Honda group for its fuel consumption, colout and design, easy handling and the respondents prefers passion for its less maintenance cost load capacity.
From the analysis it is clear that most of the respo9ndents feel not fair towards the price, lighting, cost of spares of Hero Honda group. The buyers feel excellent towards other attribute.

In modern industrial world increasing the productivity is the major trend to maximize the profit. To increase the productivity "Buyer" is very important without satisfaction of the Buyer; the manufacturer can't market their product. So the manufacturer should try to satisfy the needs and wants of the buyer.

The item or an administration, which is productive today, may not be so tomorrow. Another either replaces it or it deteriorates into profitless challenge. The basic reason is that business sectors are exceptionally unique. The days have changed and science and innovation have offered ascend to logical advertising. Presently the economy being dynamic, we are constrained to create what the market needs and the purchaser likes[31],[33].

So the production must remember and plan and create something new, so far obscure and not is presence, which will build up another monetary arrangement out of the old.

So the scientist is certain that the discoveries might be helpful for both the producers and buyers.

\section{REFERENCES}

1) BharthVajan R., Ramachandran S.,Psychographic dimensions of training,2016,International Journal of Pharmacy and Technology,V-8,I-4,P-23727-23729

2) Balakrishnan P., Bharthvajan R.,A study on human resource planning in hospitals in Chennai City,2014,International Journal of Applied Engineering Research,V-9,I-22,P-7503-7507

3) Priyadarsini P., Bharthvajan R.,Role of emotional intelligence training programme in reducing the stress of the nurses,2014,International Journal of Applied Engineering Research,V-9,I-22,P-7411-7421

4) Kerinab Beenu G., Bharthvajan R.,Empirical analysis on the cosmetic buying behavior of young women in South India,2014,International Journal of Applied Engineering Research,V-9,I-22,P-7361-7366

5) Balakrishnan P., Bharthvajan R., Whistling in the wind,2014,International Journal of Applied Engineering Research,V-9,I-22,P-7586-7593

6) Krishnan B., Peter M.,Health hazards of Indian Bpo employee-an alarming issue,2014,International Journal of Applied Engineering Research,V-9,I-22,P-7336-7341

7) Kerinab Beenu G.H., Peter M.,Role of insurance in economic development,2014,International Journal of Applied Engineering Research,V-9,I-22,P-7532-7539

8) Balakrishnan P., Peter M., Priyadarsini P.,Efficiency of safety measures for wellbeing of employees in manufacturing industry,2014,International Journal of Applied Engineering Research,V-9,I-22,P-7376-7382

9) Anbarasi M., Praveen Kumar S.,Online sales promotions of herbal products and its effectiveness towards tanisha.com,2019,Indian Journal of Public Health Research and Development,V-10,I-1,P-195-200

10) Anbarasi M., Praveen Kumar S.,Various online marketing and promotions strategies to improve the validation towards the organic products in the pharmaceutical sectors,2019,Indian Journal of Public Health Research and Development,V-10,I-1,P-263-269

11) Loganathan R., Praveen Kumar S.,Grievance handling a key factor for solving issues of employees in an organization,2014,International Journal of Applied Engineering Research,V-9,I-22,P-7483-7491

12) Loganathan R., Praveen Kumar S.,Study on preference of private label brands in super and Hypermarkets,2014,International Journal of Applied Engineering Research,V-9,I-22,P-7327-7335

13) Smitha M., Praveen Kumar S.,Understanding stress and its managementamong the nurses in Chennai city,2014,International Journal of Applied Engineering Research,V-9,I-22,P-7560-7565

14) Kerinab Beenu G.H., Praveen Kumar S.,A study on the investment behavior of Chennai investors in mutual

schemes,2014,International Journal of Applied Engineering Research,V-9,I-22,P-7520-7525 


\section{Customer Satisfaction of Different Brands of Hero Honda Motors at Rao \& Khan Motors, Krishnagiri}

15) Loganathan R., Praveen Kumar S.,Retention strategies key for organizational productivity,2014,International Journal of Applied Engineering Research,V-9,I-22,P-7443-7447

16) Pavithra J., Ganesan M., Brindha G.,State wise analysis of microfinance sector in India,2016,International Journal of Pharmacy and Technology,V-8,I-4,P-23417-23432

17) Pavithra J., Ganesan M.,A comparative study on microfinance in India and abroad,2016,International Journal of Applied Business and Economic Research,V-14,I-8,P-5471-5476

18) Pavithra J., Ganesan M.,A study on awareness and impact of micro-financial schemes,2016,International Journal of Applied Business and Economic Research,V-14,I-8,P-5449-5460

19) Senthilmurugan P., Pavithra J.,Consumer preference towards organised retailing with reference to Big Bazaar,2014,International Journal of Applied Engineering Research,V-9,I-22,P-7469-7475

20) Senthilmurugan P., Pavithra J.,Implication of social media marketing in growing healthcare industry,2014,International Journal of Applied Engineering Research,V-9,I-22,P-7448-7456

21) Loganathan R., Pavithra J.,Consumer perception towards private labe brand over other brands in super markets and hypermarkets,2014,International Journal of Applied Engineering Research,V-9,I-22,P-7355-7360

22) Kerinab Beenu G., Pavithra J.,Tradeâ€"off between liquidity and profitability in logistics industry,2014,International Journal of Applied Engineering Research,V-9,I-22,P-7398-7401

23) Kerinab Beenu G., Pavithra J.,A study on the prospective consumerâ $€^{\mathrm{TM}_{S}}$ perception towards utility cars in Chennai city,2014,International Journal of Applied Engineering Research,V-9,I-22,P-7526-7531

24) Pavithra J., Dilli Babu P., Ambuli T.V.,A study on budgetary control at Maruti Service Masters, Chennai,2014,International Journal of Applied Business and Economic Research,V-12,I-2,P-151-161

25) Pavithra J., Dilli Babu P., Ambuli T.V.,A study on customer satisfaction of retro Garments Pvt Ltd, Chennai,2014,International Journal of Applied Business and Economic Research,V-12,I-2,P-381-391

26) Kerinab Beenu G.H., Pavithra J., Senthilmurugan P.,A study on the influence of promotional activities for TATA ARIA among consumers in Chennai,2014,International Journal of Applied Engineering Research,V-9,I-22,P-7572-7578

27) Vijayaragavan S.P.,An investigative expert that's general FBG sensors,International Journal of Mechanical Engineering and Technology,V-8,I-8,PP-1500-1505,Y-2017

28) Vijayaragavan S.P.,Equalization routing protocol for Wi-Fi sensor strategy,International Journal of Mechanical Engineering and Technology,V-8,I-8,PP-1662-1666,Y-2017

29) Karthik B., Kiran Kumar T.V.U., Vijayaragavan P., Bharath Kumaran E.,Design of a digital PLL using 0.35 $\hat{\mathrm{I}}^{1 / 4 \mathrm{~m}} \mathrm{CMOS}$ technology,Middle East Journal of Scientific Research,V-18,I-12,PP-1803-1806,Y-2013

30) Kanniga E., Selvaramarathnam K., Sundararajan M.,Kandigital bike operating system,Middle - East Journal of Scientific Research,V

31) Jasmin M., Vigneshwaran T., Beulah Hemalatha S.,Design of power aware on chip embedded memory based FSM encoding in FPGA,International Journal of Applied Engineering Research,V-10,I-2,PP-4487-4496,Y-2015

32) Jasmin M.,Optimization techniques for low power VLSI circuits,Middle East Journal of Scientific Research,V-20,I-9,PP-1082-1087,Y-2014

33) Jasmin M., Vigneswaran T.,Fuzzy controller for error control of on - Chip communication,2017 International Conference on Algorithms, Methodology, Models and Applications in Emerging Technologies, ICAMMAET 2017,V-2017-January,I-,PP-1-5,Y-2017

\section{AUTHORS PROFILE}

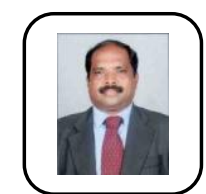

Mr. R. Ramamoorthy Assistant Professor, Department of MBA, Bharath Institute of Higher Education and Research, Chennai, India.

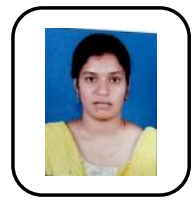

S. Soundarya Student, Department of MBA, Bharath Institute of Higher Education and Research, Chennai, India.

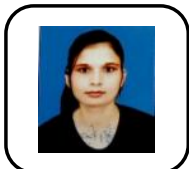

Pallavi Kumari Student, Department of MBA, Bharath Institute of Higher Education and Research, Chennai, India. 